\title{
ANNOTATIONS
}

\section{The Visual Requirements of Aviators}

An instructive discussion upon the selection of candidates for the Air Service took place at the Medical Society of London, on March 11 last. It was opened by Surgeon H. Graeme Anderson, R.N., attached R.N.A.S., whose address was published at length in the Lancet of March 16. Before entering upon the standards of fitness required for an airman, Surgeon Anderson gave his hearers some general idea of an aviator's duties in time of war. He quoted the statement that an airman's life consisted of "long spells of idleness punctuated by moments of intense fear." $\mathrm{He}$ had to face vicissitudes of weather, and was always on the look-out for hostile aircraft, watching for the flash of enemy guns, taking photographs, and noting movements of enemy troops, of rolling stock, of submarines and so forth. The opener spoke with the more authority, since he had spent the last three and a half years living and flying with aviators, entering into their interests, and studying them alike in aeroplane, seaplane and airship stations, not to mention hospitals specially devoted to their maladies. He laid the utmost stress upon the importance of the eyesight part of the physical examination of candidates for the Air Service. Indeed, he appeared to regard perfect sight as the first essential of the perfect airman. In his opinion, the latter should possess, without the aid of any glass, normal vision in both eyes, as well as in each eye separately, and also normal colour vision. These were points already insisted upon by the medical aviation authorities of the French Army and of the American Navy. Glasses for the aviator possessed dangers of their own. Surgeon Anderson recalled the case of a pupil whose defective vision was corrected by glasses, but who was making bad landings. He made three attempts to landin the first two he flattened out too soon and went up again, and on the third attempt he made a good landing. Yet that same evening he met his death in a crash. Anderson has no doubt that his glasses were displaced by his safety helmet, and that his uncorrected sight was inadequate to save him from disaster. Candidates should' be examined for latent hypermetropia, which had been found in some instances to be responsible for bad landings. A candidate reading $6 / 9$ with $+2 \mathrm{D}$. lens should be rejected. Those with heterophoria should be tested with the red and green light test, and be watched by the aerodrome doctor. Night-blindness (estimated by reading the ordinary test-type under gradual increase or decrease of illumination) was of importance only in grading pilots for night bombing. Testing for stereoscopic vision 
was hardly necessary. It was important that the candidate should possess normal reaction time (19/100 of a second).

There were aviators with defective vision who flew well, despite their disability, but Surgeon Anderson knew of many who had come to grief. "The pupil with defective vision who attempts to learn flying will probably crash." This statement, however, was qualified in the case of a pupil who had been an observer for some time, inasmuch as he would probably have learned by experience to modify his imperfect visual judgments. Anderson related the case of two pupils, each with imperfect sight, one corrected with glasses and the other not. Both learned to fly without trouble, and became good pilots, but then each had over 100 hours to his credit as an aerial observer.

In the discussion, Fleet-Surgeon R. C. Munday, R.N., spoke of the necessity of grading standards of fitness in accordance with the various flying duties, particularly the standards of sight. Questions of colour vision and the heterophoria were of vital importance. Surgeon-General Sir W. H. Norman, Director-General of the Navy Medical Service, laid stress on the importance of vision and good colour vision. Mr. E. Clarke expressed the view that every candidate's sight should be tested under a cycloplegic. Captain H. D. Briggs, R.N., thought that those with doubtful sight should fly alone, as they had no right to involve others in a risk which they took themselves. Sir James Galloway asked for some standardized method for the examination of colour vision. Mr. L. Vernon Cargill agreed as to the importance of heterophoria as a cause of accidents. Colour vision should be tested with the EdridgeGreen lamp. Stereoscopic vision and a perfect visual field in each eye were very necessary.

\section{American College of Surgeons}

Revised requirements for admission to the Fellowship of the American College of Surgeons, which have grown out of the experience gained by the College during the past four years, have recently been issued. Among important changes are those which aftect ophthalmologists who are candidates for the distinction. The new scheme as regards them will be worked out in co-operation with the American Board for Ophthalmic Examinations, which for the time being will be the same body as the Ophthalmic Credentials Committee of the College, the members of which are: Edward Jackson (Denver), Frank C. Todd (Minneapolis), William H.Wilder (Chicago), Edward C. Ellett (Memphis), Walter B. Lancaster (Boston), Hiram Woods (Baltimore), Myles Standish (Boston), and John E. Weeks (New York). In addition to the general requirements for admission to the Fellowship (except in regard to examinations in surgery to which ordinary candidates are subjected), 